Marina S. Cvetković

University of Belgrade

Teacher Education Faculty

marina.cvetkovic@uf.bg.ac.rs

\title{
IMPACT OF FORMATIVE ASSESSMENT ON THE CONFIDENCE OF YOUNG LEARNERS IN THE SECOND LANGUAGE CLASSROOM
}

\begin{abstract}
The aim of this paper is to explore the benefits of formative assessment and to show how formative assessment tasks can impact confidence and motivation of young learners in the second language classroom. It presents a small scale study and its findings indicate that students perform much better if they receive feedback on their performance on a regular basis and that formative assessment tasks could be a way to enhance student motivation and thus improve language acquisition.
\end{abstract}

Key words: English as a Second Language, formative assessment, confidence, feedback.

\section{UTICAJ FORMATIVNOG OCENJIVANJA NA SAMOPOUZDANJE UČENIKA U NASTAVI DRUGOG JEZIKA}

APSTRAKT: Cilj ovog rada je da istraži dobre strane formativnog ocenjivanja i pokaže da zadaci formativnog ocenjivanja mogu uticati na samopouzdanje i motivaciju dece koja uče drugi jezik. Istraživanje koje predstavljamo je manjeg obima i njegovi rezultati pokazuju da učenici postižu bolje rezultate ukoliko redovno dobijaju povratne informacije tako da formativno ocenjivanje može motivisati učenike i dovesti do boljeg usvajanja jezika.

Ključne reči: engleski kao drugi jezik, formativno ocenjivanje, samopouzdanje, povratne informacije.

\section{INTRODUCTION}

The increasing mobility of people implies an increasing number of children who start mastering two or more languages and often follow instruction in a language that is different from their mother tongue. When those students are enrolled in school, they often face a lot of difficulties. The main source of their difficulties is not knowing the language of instruction. They need the language for social purposes as well as for academic purposes. In English speaking schools, 
those students are classified as English as a Second Language (ESL) students and they receive additional English support.

Until those students have enough knowledge of the language of instruction, they struggle with their work in different subject areas. Although subject teachers provide encouragement by creating opportunities for students to work in a supportive environment, some students often disengage themselves from the activities and work quietly on their own. When trying to identify the reasons for this behaviour, affective environment in the mainstream classrooms is often overlooked as a possible source of student problems. As those students enter classrooms with the fear of using a language that they do not know well enough, there are increasing chances that anxiety will affect the learning process and that their self-confidence will be damaged (see e.g. Mihaljević Djigunović 2009). Students are often placed in the uncomfortable position of trying to express complex ideas with inadequate language and that inevitably impacts their selfesteem.

Self-confidence is considered to be an important aspect in second language acquisition. The concept of linguistic self-confidence is introduced by Clément (1980) and is related to a person's belief that they can perform in another language. Clément (1986: 273) stresses that "self-confidence is directly related to motivation and proficiency". Indeed, the way students perceive their competence may impact the level of their participation in class activities. Therefore, language teachers who provide additional support for the students usually work not only on language skills of their students, but on helping students become more confident language users. Arnold (2011: 16) states that "experiencing real achievement in using the target language in meaningful communication is the surest route to self-esteem". De Andreas and Arnold (2009: 13) point out that "self-esteem can be nurtured through successful learning experiences, which enable learners to see themselves as competent". Students need to be placed in situations where they want to communicate and feel safe to do so. To help students develop, teachers need to be encouraging and to provide timely feedback on their performance.

Assessment is an integral part of instruction. Assessment practices need to be carried out in a way that does not cause anxiety. Clark (2012: 28) emphasizes the importance of instruction and assessment, pointing out that they have "the profound influence on ... motivation and self-esteem". The focus of any language instruction with young learners is on creating opportunities for students to interact and become more engaged with the language. Appropriate assessment tasks are those that are relevant to student interests and experiences and have a format similar to class activities. Cameron (2001: 220) suggests using assessment 
activities that are familiar to children from their classroom experience. Familiarity can help reduce the level of anxiety that is created by the fear of making mistakes and feeling of success by stressing communicative fluency.

The primary purpose of formative assessment is to promote learning and it is seen as informal and frequent. It is focused on gathering information about students and their language learning needs while they are still learning (Davidson \& Leung 2009: 397). Formative assessment helps students improve their performance and teachers identify what aspects of instruction need to be changed. Students who are in the process of learning something new integrate this new content in the familiar one and in that way they use their previous knowledge.

Formative assessment is a tool that helps teachers determine what problems their students may have (Murray \& Christison 2010). Students also need to understand what they learned and what they need to change to improve their language performance. Formative assessment tasks are ongoing and provide the teacher with the opportunity to give necessary feedback to their students (see e.g. Taras 2005). An assessment task is formative when teachers and students use "evidence about student achievement... to make decisions about the next step in instruction" (Wiliam 2011). This kind of tasks should provide students with ongoing and meaningful feedback on their work, which needs to be positive and specific by stating what students can already do and what needs to be improved. The expectations have to be communicated clearly. An integral part of formative assessment should be the teacher's descriptive feedback. Prolman (2017) points out that the achievement in classes in which effective feedback is provided to students is considerably higher than the achievement in classes where there is no descriptive feedback. When feedback focuses on a formative assessment task, students will have time to redo their work and in that way they would improve their performance (Frey \& Fisher 2013). Therefore, descriptive feedback improves not only academic achievement but also student confidence.

\section{THE STUDY}

\subsection{Context}

This small scale qualitative study was conducted in a privately owned school in Serbia where English is the language of instruction. The school enrolls both Serbian and non-Serbian children. The majority of students come from nonEnglish speaking countries and they either learn English as a second language or they had attended additional English classes at some point in their schooling. The 
aim of the small scale study was to show how formative assessment tasks impact confidence. The study attempted to discover the relationship between formative assessment activities and confidence and the relationship between feedback and student confidence to use English.

The study was carried out with eight students aged 10 and 11 over the period of seven months, from September to March. The students involved in this study attended an English as a Second Language (ESL) class because they needed additional English support to manage academic demands of other classes. Since their academic success depended on their language proficiency, the students were painfully aware of their need to improve English. Their use of language created additional tension because the perception that the core subject teachers had of their students' performance was impacted by the lack of the students' language proficiency. ESL students were not vocal in other classes and generally participated less than other students. Their insecurity impacted the way teachers would perceive their language proficiency.

Although the group was small, the students had very different needs and from the very beginning there were two distinctive groups. The first group consisted of students who had learned English in an international setting before,and for whom this was not their first year of learning in an environment where English is the language of instruction. The students in this group had already developed strategies and were chatty in English. Their main problem was writing. They struggled with spelling, sentence structure, and organization. The second group consisted of students who had just joined the school. They had learned English prior to enrolling in this international school, but only as a foreign language. The students from the second group were concerned with linguistic accuracy and would often refuse to engage in a discussion or to volunteer giving an answer. They lacked confidence and were reluctant to speak for fear of not being understood.

Both groups needed to improve confidence in different areas. The first group needed to work on their reading and writing skills. They complained that reading was tedious, that writing was meaningless, and insisted that they needed to have fun in order to learn. The second group liked fun activities, but during these activities they were quiet and tried to avoid conversation with other students. Since both groups needed to work on language accuracy and fluency and both groups needed to engage with activities that would increase their confidence, the teacher needed to find ways to inform students of their progress that would not negatively impact their confidence. Therefore, the teacher incorporated a number of formative assessment tasks into the instruction process, such as opinion sharing activities, reasoning gap activities and other communicative language learning activities. 
These activities provided a framework for the teacher to offer feedback on their progress and to offer strategies for further student development. Formative assessment gave students the direction they needed and they could easily see the small steps they had to take that would lead them to better performance. It also meant that students would ask clarifying questions and engage in conversation with the teacher and other students more often.

\subsection{Data}

The tools for data collection were observation, feedback sessions from a storyline ongoing project that lasted over four months, a reflective drawing task that was used to encourage students to think about their progress, and informal interviews with the mainstream teachers.

\subsubsection{Observations}

One context specific issue in data collection was the use of the second language. Since there was no first language that was shared by all students, the data were collected through their second language - English. It was necessary to use English, but some students were not able to express themselves well in the second language. Therefore, the teacher had to design learning activities that would allow students to express their opinion, but that did not require high language proficiency.

While the students worked on the tasks, the teacher observed the class, took notes and, in some cases, filled in checklists, which provided a "snapshot" of what was going on at any given moment. The teacher checked if the students were finding the information independently, what the students were doing while engaged in learning activities, what choices they made about the activities, and captured details of student-student interactions (for example, if students used humour to encourage each other).

\subsubsection{The ongoing storyline $e^{l}$ project}

\footnotetext{
${ }^{1}$ Storyline approach was developed at the Faculty of University of Strathclyde in the 1960. It provides a structure for classroom engagements. Teacher designs the storyline, sets it in a particular time and place, introduces characters and problems to be solved. Students then develop the story and provide information about the characters. Characters "experience" situations that often reflect issues relevant to students. Problems have to be overcome by
} 
The majority of the data was gathered through teacher designed activities that were intended to be assessment tools. The formative assessment tasks resembled the activities that students of that age perform in other mainstream classes: discussions, simple writing tasks, etc. These tasks presented opportunities to gather evidence of student learning through spontaneous interaction. There were also written reflections after some lessons and they would encourage students to think about their performance and ways to improve it. To provide possibilities for the necessary opinion exchange, the teacher introduced a project based on a storyline approach that encouraged the students to work on English and on skills, but also provided an opportunity for the students to talk about their feelings and attitudes. The teacher created the storyline which presented only the framework for different activities that would come later. The students were actively engaged in the process of designing the framework of the task and they developed the story, characters, suggested conflicts, and worked on solutions for those conflicts. The framework provided an all important context for writing and speaking. The students did not have to spend so much time simply trying to think of something to write about. They also had the opportunity to work together with others developing their communication skills in the situations that they designed. The activities also involved the teacher and, in that way, enabled the teacher to provide appropriate scaffolding and to give immediate feedback. The teacher kept a journal in which the students' comments, as well as their reactions to the task, were recorded. Based on student interaction and involvement, the teacher designed additional assignments that prompted the students to practice the language they needed. The entries provided a number of anecdotal records that helped the teacher to determine if the students were gaining confidence in language use.

\subsubsection{The reflective drawing task followed by a discussion session with the students}

The interview session with all the students was meant to be one of the data collection tools during the initial stages of the research. At that time, a whole group interview seemed like a good idea, however, it was not used that for several reasons. The students, who were in an English medium school for the first time that

involving characters in negotiation and collaboration. In this way, students use the language and practice problem solving. The project usually lasts a longer period of time, characters develop, problems are solved and new issues appear. More about story line in Bell, Harkness and White, 2007. 
year, could not participate in a group discussion in the same way as the students who were more confident using English. They were usually very quiet and shy and would not contribute during the discussion if not asked to do so. If they were asked for their opinion, they would give very short answers. It was no surprise that some students monopolized the discussion for the simple reason that they were the only ones who would attempt to share an opinion. Another reason for not using group interviews was the difficulty to ask probing questions in such an environment. To avoid situations in which only one group of students would contribute, the drawing task was introduced. The students were asked to reflect on their language learning at the beginning of the school year and at the end. They were instructed to draw two images. The first image would represent them at the beginning of the year and the second image would represent them towards the end of the school year. After they completed the drawings, they were asked to explain the changes that took place during the course of the year. The students shared their insights with the whole group and both the teacher and the students would ask clarifying questions. Those questions encouraged the students to talk about the change in their language proficiency and about the obstacles they had in the process. The discussions were recorded and later transcribed. This reflective task was open-ended, it presented the students with a stimulus and allowed them to communicate an original response. The students' comments are given verbatim.

\subsubsection{Informal interviews with mainstream teachers}

Another way of obtaining the data was through informal interviews with the mainstream teachers. During these meetings, the needs of the students were discussed. Subject teachers often complained about the lack of participation of ESL students. They reported their concerns and sometimes frustrations. At the end of a term during the meetings, their progress was considered. The subject teachers' comments were used as a one of the indicators for determining the students' language proficiency and their language progress.

\section{FINDINGS AND DISCUSSION}

The mainstream teachers and ESL teachers had a very different perception of what the students could do with their limited English. Initial interviews with the mainstream teachers identified their concern that low-level ESL students interact less in the mainstream classroom, choosing not to take part in tasks that demand interaction with peers. To help low-level students, some teachers tried arranging 
their classes so that the students could work in small groups, hoping that in that way more proficient English students would help ESL students. However, even in these situations, the teachers reported that ESL students would withdraw from contacts with other students. These experiences influenced the teachers' perception of ESL students and they had lower expectations. It appears that in this situation, lowering the expectations affected the students' motivation and their self-esteem, which then had an impact on learning generally and language learning in particular. On the other hand, the dynamics of the ESL class was different. The students interacted freely and often asked the ESL teacher to help them with their core subject assignments. In these situations, the ESL teacher would scaffold the language so that the students could carry out the task.

\subsection{Increasing student confidence}

Based on the students' comments and the ESL teachers' observation, there seems to be a strong relationship between class activities and confidence. When the students like the activities and see their relevance, they are willing to participate and that desire impacts the atmosphere. This is especially the case when the students participate in designing activities. One student said: "I like when we talk about what we did well." The observations of student interactions helped to determine that they were highly engaged in the work they were doing and proud of their accomplishments. When asked what they thought about the "house project,"2 one student reported, "We do fun stuff and don't get tired." Another student commented: "It was like a game." One student was aware that the practice she had in the ESL class was helpful to get more involved in other classes: "I speak in class more, not only in this class, but in all classes." One student suggested that mastering English would provide an opportunity for him to learn another foreign language: "When my English is good, I will go to French class". Overall, the impression was that the students gained confidence through formative assessment tasks that provided them with the opportunities for language development. Activities also helped the students increase their comfort zone and feeling of success.

\footnotetext{
2 "House project" refers to the Storyline activities.
} 


\subsection{Increasing classroom participation}

The students had a lot of opportunities to use the foreign language and they were aware that discussing different issues with their peers helped them improve it. The game-like activity would prompt the students to speak, share opinions, and play an active role in all situations that evolved from the project. That would give the students the necessary practice: they would participate in discussions, take turns appropriately, and express their ideas and concerns. Also, the students were aware that they were doing better socially. "I am faster in talking or chatting/writing with friends." One student pointed out that her negotiation skills had improved. "I had a fight with XX. Last year I did not fight. This year I fight more... with words." This student had been very quiet the previous year and would not disagree with her peers. Gradually, she felt more confident to express her opinion and disagree openly (she used the word 'fight' in this sense) with students. She was also aware that she could express her ideas more frequently this year. Another student who still struggles with pronunciation explained that other teachers did not understand her all the time. "You understand what I say," she explained to the EAL teacher, "I try to explain to other teachers, too." Teacher actions affected how the students approached their work, spending more time in individual conversations building closer relationships with other students.

There is also a relationship between feedback and the students' confidence in using English. Findings indicate that students perform much better if they receive feedback on their performance on a regular basis and that formative assessment tasks could be a way to enhance student motivation and thus improve language acquisition. Discussing progress with the students regularly helped them keep focused. The students often point out that they still do not know English well. One student both complained and recognized the learning that took place, "I always make mistakes... you tell me that I am wrong... I think next time... and I do not say wrong words." But there were those who felt that they had improved academically. One student shared: "I can read more books now," and another student commented: "I study faster now."

\section{CONCLUSION}

Formative assessment is beneficial both for teachers and students. Language learning experiences that are used as formative assessment tasks provide teachers with valuable information about their students' progress. The activities used for formative assessment also identify if some aspects of instruction need to 
change. Through formative assessment tasks, students receive feedback from the teacher that helps them improve performance and perform well on summative assessment tasks.

Formative assessment is often called assessment for learning and can be included in various stages of the learning process. By shifting the focus from summative assessment to formative assessment tasks teachers gain more insights into students' progress and that can inform the instruction. There is the potential of formative assessment to improve instruction. This small-scale study supports the idea that regular feedback from the teacher and peers contributes to the quality of work of young learners. During ESL instruction the students practice using the language they need and in that way gain confidence in using the language they know in unfamiliar situations. Many of the strategies that are used by ESL teachers need to be included into the teaching repertoire of core subject teachers so that second-language learners understand task clarifications and have successful learning experience. Including activities that require group work and enable students to practice language with their peers, or pre-teaching sentence openers to give students practice with language are some of the strategies that could be used by core subject teachers to help second language learners to express their ideas and show the understanding of concepts.

Formative assessment has a holistic component. It teaches students how to learn and to improve their study skills, social skills and academic skills. Feedback that students receive during and after formative assessment tasks provides the direction students need to take in order to improve. Additional efforts from teachers should focus on asking questions that require students to demonstrate their reflection about their learning process. Training students to give feedback to their peers improves strategic competence. Students learn how to react positively to correction and how to correct others appropriately. They also learn to accept each other through giving feedback. There is less fear of correction and students develop appropriate ways of pointing out to others how something should be communicated. Students are encouraged when their peers follow what they are saying. The classroom becomes more of a community, there is less competition, and students learn from each other and not only from the teacher. Formative assessment is not high stake assessment. Creating a good atmosphere and group dynamics impacts classroom atmosphere and if there is a positive atmosphere in the classroom, students will react positively to feedback and be more prepared to learn from their mistakes. 


\section{REFERENCES}

Arnold, J. (2011). "Attention to Affect in Language Learning". Anglistik. International Journal of English Studies 22: 11-22.

de Andreas V., J. Arnold (2009). Seeds of Confidence. Languages.

Bell, S., Harkness, S., G. White. (2007). Storyline - Past, Present and Future. Glasgow: Enterprising Careers, University of Strathclyde.

Cameron, L. (2001). Teaching languages to young learners. Cambridge: Cambridge University Press.

Clark, I. (2012). "Formative Assessment: A Systematic and Artistic Process of Instruction for Supporting". Canadian Journal of Education 35: 24-40.

Clément, R. (1980). "Social and individual factors in second language acquisition". Canadian Journal, of Behavioral Science, 12, 293-302.

Clément, R. (1986). "Second language proficiency and acculturation: An investigation of the effects of language status and individual characteristics". Journal of Language and Social Psychology, 5, 271-290.

Davidson C., C. Leung (2009). "Teacher Based Assessment: An International Perspective on Theory and Practice". TESOL Quarterly 43: 393-415.

Frey, N. \& Fisher, D. (2013). "A Formative Assessment System for Writing Improvement". The English Journal 103: 66-71.

Kuchah, K., A. Pinter (2012). "Was this an interview? Breaking the power barrier in adult-child interviews in an African context". Issues in Educational Research 22: 283-297.

Mihaljević Djigunović, J. (2009). Individual differences in early language programmes, in The Age Factor and Early Language Learning, ed. M. Nikolov (Berlin/New York: Mouton de Gruyter): 99-225.

Murray, D. E., M. Christison (2010). What Language Teachers Need to Know, New York: Routledge.

Prolman, F. (2017). Building Your Instructional Leadership. The Learning Collaborative.

Taras, M. (2005). "Assessment - summative and formative: Some theoretical reflections". British Journal of Educational Studies 53: 466-478.

Wiliam, D. (2011). "Embedded formative assessment". Solution Tree Press. Accessed 9 September 2018. URL: http://www.tdschools.org/wpcontent/uploads/2012/07/The-Main-Idea-Embedded-FormativeAssessment-March-2013.pdf 
Olja R. Milošević

Međunarodna škola u Beogradu

Marina S. Cvetković

Univerzitet u Beogradu

Učiteljski fakultet, Beograd

\section{UTICAJ FORMATIVNOG OCENJIVANJA NA SAMOPOUZDANJE UČENIKA U NASTAVI DRUGOG JEZIKA}

\section{Sažetak}

Za razliku od klasičnog ocenjivanja kojim se vrednuje savladanost određene nastavne jedinice ili učenikov rad tokom dužeg perioda, formativno ocenjivanje naglasak stavlja na proveru stepena napredovanja učenika, kao i na donošenje zaključaka u vezi sa aspektima nastavne jedinice na koje nastavnik dodatno treba da obrati pažnju. Upravo iz tog razloga, formativno ocenjivanje se često smatra ocenjivanjem koje pomaže nastavnom procesu. Formativno ocenjivanje može biti uključeno u bilo koji deo časa. Različite aktivnosti koje se inače sprovode u toku nastave mogu imati elemente formativnog ocenjivanja. Nastavnik brzo može da stekne uvid u to koliko je učenika ovladalo određenim sadržajem, a učenici dobijaju uputstva od nastavnika koja će im pomoći da postignu još bolje rezultate.

Ovaj rad predstavlja rezultate istraživanja koje je sprovedeno u jednoj školi u kojoj se nastava izvodi na engleskom jeziku sa decom koja engleski uče kao drugi jezik i nalaze se u različitim fazama ovladavanja jezikom. Rezultati ukazuju na to da su aktivnosti koje u sebi sadrže elemente formativnog ocenjivanja podsticale učenike da razmišljaju o svom radu i koriguju ga u skladu sa uputstvima koja su dobijali od nastavnika, te da su ponavljanjem delova zadataka postizali bolje rezultate. Ovaj proces je uticao na samopouzdanje učenika jer su postajali svesni svog napretka. Poboljšale su se i učeničke komunikacione veštine jer se od njih očekivalo da opišu koje su izmene unosili u svoj rad, kao i da objasne šta planiraju da urade kako bi ovladali određenim jezičkim aspektima.

Ključne reči: engleski kao drugi jezik, formativno ocenjivanje, samopouzdanje, povratne informacije.

Received: 11 April 2019

Accepted: 26 June 2019 